\title{
BONE MINERAL DENSITY AND JUMPING HEIGHT IN PRE-MENARCHEAL AND POST-MENARCHEAL PHYSICALLY ACTIVE GIRLS
}

\author{
Rita Gruodyte் ${ }^{1,2}$, Toivo Jürimä $\mathrm{e}^{3}$ \\ Lithuanian Academy of Physical Education ${ }^{1}$, Kaunas, Lithuania \\ University of Saskatchewan², Saskatchewan, Canada \\ University of Tartu ${ }^{3}$, Tartu, Estonia
}

\begin{abstract}
Research background and hypothesis. Jumping ability correlates well with different bone values. The skeletal benefits of high-impact weight-bearing exercise have been shown to be greater when training is started prior to menarche. We hypothesized that significant differences would be apparent in the relationships between bone values and jumping height in favor of the girls' prior menarche compared to post-menarcheal group.

Research aim. The aim of the study was to investigate the relationships between jumping height and bone mineral density (BMD) in pre-menarcheal and post-menarcheal physically active girls.

Research methods. In total, 113 adolescent girls from different competitive extramural athletic programs participated in this study. Femoral neck and lumbar spine BMD were measured. The heights of vertical jumps (i. e. countermovement jump (CMJ) and rebound jumps for 15 (RJ $15 \mathrm{~s}$ ) and 30 (RJ $30 \mathrm{~s}$ ) seconds) were obtained.

Research results. After adjusting for major confounders (i. e. age, height, and body mass), the height of rebound jumps correlated only with femoral neck BMD and only in pre-menarcheal group $(r=0.37-0.46 ; \mathrm{p}<0.05)$. No correlations were found between BMD variables and jumping height in post-menarcheal girls. The height of CMJ did not correlate with measured BMD variables in the studied groups.

Discussion and conclusions. Early puberty is an opportune period to increase bone adaptation to mechanical loading due to the velocity of bone growth and endocrine changes at this time. We suggest that powerful repetitive vertical jumping may be more beneficial to bone health compared to single jumping activities in physically active girls prior to menarche rather than after it.
\end{abstract}

Keywords: bone health, vertical jumps, puberty.

\section{INTRODUCTION}

$\mathrm{R}$ egular high-impact weight-bearing physical activity (such as ball games, racket sports, gymnastics, dance, running, or jumping exercises) during growth may play an important role in maximizing bone mineral mass gain which may reduce the incidence of fractures in children and adolescents as well as in the elderly (Misra, 2008; Rizzoli et al., 2010). Early puberty is a period for increased bone adaptation to mechanical loading due to the velocity of bone growth and endocrine changes at this time (Hind, Burrows, 2007). The two critical years for accumulating more than $25 \%$ of adult bone in girls correspond to the ages 11.513.5 (MacKelvie et al., 2002). The skeletal benefits of exercise have been shown to be greater when training is started prior to menarche (Heinonen et al., 2000). Of different exercise modalities, highimpact activity, for example, jumping, seems to be especially osteogenic (MacKelvie et al., 2002). Several studies have reported high-impact jumping exercise interventions to be an effective bone stimulus in females at pre-puberty, adolescence 
or young adulthood (MacKelvie et al., 2003; Kato et al., 2006; Gunter et al., 2008). Jumping ability seems to correlate well with different bone values: different vertical jumps have been used to evaluate jumping ability in young athletes (Kellis et al., 1999). In our previous study (Gruodyte et al., 2009) we attempted to investigate the relationships between bone mineral values and jumping ability in pubertal girls in relation to the different loading patterns of their selected sports. The main finding of the study was that jumping height correlated with bone variables in girls who experienced continuous high-impact physical activity, such as sport games and rhythmic gymnastics (Gruodyte et al., 2009). However, little is known about the possible relationships between maximal vertical jumping height and bone parameters in adolescent female athletes with regard to the menarche.

The aim of the current study was to evaluate the relationships of BMD at femoral neck and lumbar spine with jumping height of single maximal jump and repetitive rebound jumps for 15 and 30 seconds in physically active girls in relation to menarche. Would the significant differences be apparent in pre- and post-menarcheal groups in regard to the relationships between bone values and jumping height? We hypothesized that it should be - in favor of the girls' prior menarche compared to post-menarcheal group.

\section{RESEARCH METHODS}

In total, 113 healthy $13-15$-year-old physically active girls participated in this cross-sectional study. The girls were recruited from national sport associations and local clubs in Estonia. The volunteers participated in the selected competitive extramural athletic programs (such as gymnastics, volleyball, basketball, badminton, track and field sprint) at least for two years. The study subjects were divided in pre-menarcheal $(\mathrm{n}=36)$ and post-menarcheal $(n=77)$ groups. A full written description of the nature of the study was provided both to the girls and their parents before obtaining their informed written consent. The study was approved by the Medical Ethics Committee of the University of Tartu (Estonia).

Height and body mass were measured to the nearest $0.1 \mathrm{~cm}$ and $0.05 \mathrm{~kg}$ respectively, using the Martin's metal anthropometer and medical scales ( $A \& D$ Instruments Ltd, UK). Body mass index (BMI) $\left(\mathrm{kg} / \mathrm{m}^{2}\right)$ was calculated using height and body mass data. A simple questionnaire was used to obtain the information about the onset of the training and weekly hours of participating in weight-bearing physical activities. The girls were also asked if they had experienced menarche. If positive, they were asked to recall the age when menarche occurred. Gynecological age (years) was calculated subtracting the athlete's self-reported age at menarche from her chronological age (Barkai et al., 2007).

Bone mineral density $\left(\mathrm{g} / \mathrm{cm}^{2}\right)$ at lumbar spine (L2-L4) and femoral neck were measured using dual-energy X-ray absorptiometry (DXA; DPXIQ, Lunar Corporation, Madison, WI, USA). Participants were scanned in light clothing while lying flat on their backs with arms at their sides. DXA measurements and results were evaluated by the same examiner. Coefficients of variations for BMD measurements were less than $2 \%$.

The maximal height of two-foot hands-on-thehips vertical jumps was measured using contact mat (Newtest OY, Finland) which was connected to a digital recorder that calculated the flight height. The girls have performed three jumping tests in the following order: (1) a countermovement jump (CMJ) from a standing position with a preliminary countermovement; (2) the rebound jump, with continuous countermovement jumps for 15 seconds (RJ $15 \mathrm{~s}$ ); and (3) the rebound jump for 30 seconds (RJ 30 s) (Kellis et al., 1999). In CMJ, the best result out of three attempts was recorded. The girls were instructed and then verbally encouraged to jump as high and as rapidly as they could. The hands remained on waist throughout all jumping tests to avoid upper extremities contribution to the jump height (Kellis et al., 1999). Each subject performed RJ $15 \mathrm{~s}$ test immediately after CMJ test; and RJ $30 \mathrm{~s}$ test after a sufficient rest period (i. e. after another subject had performed CMJ and RJ $15 \mathrm{~s}$ tests).

Statistical analysis was carried out using SPSS 15.0 package for Windows. Standard statistical methods were used to calculate means and standard deviations $( \pm \mathrm{SD})$. A one-way analysis of variance (ANOVA) was used to establish the differences between the groups. Pearson's correlation coefficients were computed to identify relationships between jumping performance and BMD variables. Partial correlation analysis was used to examine this relationship after controlling for major confounders (i. e. age, body height, and body mass). A significance level of 0.05 was used. 


\section{RESEARCH RESULTS}

The physical and performance characteristics of the study subjects are presented in Table 1 . The significant differences between the two groups were found in age, height, body mass, BMI, amount of the weekly hours of training, and BMD variables. The results of jumping tests did not differ significantly between the groups of pre-menarcheal and post-menarcheal girls (Table 1).

The significant correlations $(r=0.33-0.48$; $\mathrm{p}<0.05$ ) were revealed between BMD variables and rebound jumps in pre-menarcheal girls (Table 2). After the adjustments for age, height, and body mass were performed, the significant relationships of rebound jumps were found only with BMD at femoral neck in pre-menarcheal girls only. The relationships between BMD variables and CMJ were not significant $(\mathrm{p}>0.05)$. No significant associations between measured BMD variables and jumping test results were found in post-menarcheal group of physically active girls.

\section{DISCUSSION}

Although there have been numerous interventions, implementing jumping exercise to augment bone health, there is a dearth of data quantifying the relationships between jumping height and bone values. The results of present crosssectional investigation demonstrated that BMD at femoral neck and lumbar spine significantly correlated with rebound jumps for 15 and 30 seconds in physically active girls only from the pre-menarcheal group. The relationships remained significant between BMD at femoral neck and rebound jumps after controlling for age, height, and body mass, suggesting that BMD at femoral neck is more sensitive to the mechanical loading and weight-bearing physical activity than lumbar spine, and it was observed in pre-menarcheal but not in post-menarcheal girls. This could be explained by the fact that skeletal response to the weight-bearing exercise is site-specific. Numerous

\begin{tabular}{|l|c|c|}
\hline \multicolumn{1}{|c|}{$\begin{array}{c}\text { Physical and performance } \\
\text { characteristics }\end{array}$} & $\begin{array}{c}\text { Pre-menarcheal girls } \\
(\mathbf{n}=\mathbf{3 6})\end{array}$ & $\begin{array}{c}\text { Post-menarcheal girls } \\
(\mathbf{n}=77)\end{array}$ \\
\hline Age, years & $13.6 \pm 0.9$ & $14.4 \pm 0.9^{* *}$ \\
\hline Height, cm & $163.1 \pm 7.7$ & $167.7 \pm 6.7^{*}$ \\
\hline Body mass, kg & $49.7 \pm 7.7$ & $57.8 \pm 8.6^{* *}$ \\
\hline BMI, kg/m² ${ }^{2}$ & $18.6 \pm 2.2$ & $20.5 \pm 2.5^{* *}$ \\
\hline Gynecological age, years & - & $1.9 \pm 1.0$ \\
\hline Years of training & $4.6 \pm 2.3$ & $4.5 \pm 2.0$ \\
\hline Training duration, $\mathrm{h} / \mathrm{w}$ & $7.3 \pm 4.2$ & $5.4 \pm 2.4 *$ \\
\hline Femoral neck BMD, g/cm ${ }^{2}$ & $1.004 \pm 0.132$ & $1.091 \pm 0.109 * *$ \\
\hline Lumbar spine BMD, $\mathrm{g} / \mathrm{cm}^{2}$ & $1.021 \pm 0.117$ & $1.151 \pm 0.110^{* *}$ \\
\hline CMJ, cm & $27.6 \pm 3.5$ & $26.2 \pm 4.1$ \\
\hline RJ $15 \mathrm{~s}, \mathrm{~cm}$ & $23.2 \pm 3.4$ & $22.4 \pm 3.4$ \\
\hline RJ $30 \mathrm{~s}, \mathrm{~cm}$ & $22.3 \pm 3.5$ & $21.6 \pm 3.4$ \\
\hline
\end{tabular}

Table 1. Mean ( \pm SD) physical and performance characteristics of the study subjects

Note. BMI - body mass index BMD - bone mineral density; CMJ - countermovement jump; RJ $15 \mathrm{~s}$ - the rebound jump for 15 seconds; RJ $30 \mathrm{~s}$ - the rebound jump for 30 seconds. Significant differences between the groups are indicated with asterix: ${ }^{*}-\mathrm{p}<0.01 ; * *-\mathrm{p}<0.001$.

\begin{tabular}{|l|c|c|}
\hline \multicolumn{1}{|c|}{ BMD variables } & $\begin{array}{c}\text { Pre-menarcheal girls } \\
(\mathbf{n}=\mathbf{3 6})\end{array}$ & $\begin{array}{c}\text { Post-menarcheal girls } \\
(\mathbf{n}=\mathbf{7 7})\end{array}$ \\
\hline Femoral neck BMD, g/cm² & & $0.13(0.20)$ \\
\hline CMJ, cm & $0.04(0.02)$ & $0.12(0.22)$ \\
\hline RJ $15 \mathrm{~s}, \mathrm{~cm}$ & $0.48^{* *}\left(0.46^{* *}\right)$ & $0.08(0.22)$ \\
\hline RJ $30 \mathrm{~s}, \mathrm{~cm}$ & $0.43^{* *}\left(0.37^{*}\right)$ & \\
\hline Lumbar spine BMD, g/cm ${ }^{2}$ & & $0.09(0.15)$ \\
\hline CMJ, cm & $0.13(0.21)$ & $0.11(0.19)$ \\
\hline RJ15 s, cm & $0.33^{*}(0.32)$ & $0.14(0.24)$ \\
\hline RJ30 s, cm & $0.34^{*}(0.29)$ & \\
\hline
\end{tabular}

Table 2. Pearson's correlation for BMD variables and jumping height in pre-menarcheal and post-menarcheal girls. Partial correlation analysis (controlled for age, height, and body mass) is presented in brackets

Note. BMD - bone mineral density; CMJ - countermovement jump; RJ 15 $\mathrm{S}$ - rebound jump for 15 seconds; RJ $30 \mathrm{~s}$ - rebound jump for 30 seconds. Significant differences between the groups indicated with asterix: ${ }^{*}-\mathrm{p}<0.05$; $* *-\mathrm{p}<0.01$. 
physical activity intervention trials, aiming to increase BMD, report the most significant effects at the femoral neck, because they include different jumping exercises that generate impact forces through the lower limbs, hence creating a greater loading at the hip than at the spine (Hind, Burrows, 2007). On the other hand, exercise seems to be more beneficial for additional bone mineral acquisition before menarche (i. e. during the growth spurt) rather than after it, which may be due to the increase of estrogen and free, biologically active insulin-like growth factor-1 (IGF-1) levels occuring between the ages 11.5-13.5, corresponding to the timing of menarche and peak bone mineral accrual velocity (MacKelvie et al., 2002). The results of a 9-month exercise intervention study by A. Heinonen et al. (2000) indicated that mechanical loading exercise intervention had significantly greater impact on bone mineral content (BMC) increase at lumbar spine and femoral neck in exercising premenarcheal girls compared to exercising postmenarcheal girls or controls. Despite the fact that increase in bone mineral in the growing girls may be attributable to growth itself, A. Heinonen et al. (2000) study reported significant additional bone gain after the intervention in premenarcheal girls only. In contrast, H. S. Barkai and colleagues (2007), in a study of 13-18-year-old girls participating in structured weight-bearing sports, found the strongest associations of the amount of weightbearing exercise with BMD at the spine, hip, and total body in postmenarcheal group. Nevertheless, these results must be interpreted cautiously, since almost a third of the study population reported having no structured sports participation before menarche (Barkai et al., 2007). Menstrual history is a strong predictor of bone mineral density: delayed menarche may cause lower peak bone mass attainment or may be a marker for other possible influences on stress fracture risk such as low body fat, low body weight, future menstrual disturbance, or excessive training (Pepper, SaintPhard, 2007). In contrast to the regular weightbearing physical activity, excessive training may have a negative impact on bone health. Girls and women participating in sports very intensively, and especially in those that emphasize a low body weight (such as gymnastics, running, or ballet) are more likely than other active women to expose themselves to the detrimental condition named the female athlete triad (i. e. disordered eating, menstrual dysfunction, and low bone density) (Manore et al., 2007).

Maximum vertical jump performed from the standing position with a countermovement (CMJ) as well as rebound jumps for 15 (RJ $15 \mathrm{~s}$ ) and 30 (RJ 30 s) seconds reflect well jumping abilities in young athletes (Kellis et al., 1999). In turn, jumping height may be influenced by different factors, such as muscle fibre type composition, lean body mass, muscular strength, age, anthropometric parameters and/or angle of the legs bent in knee joints at the take off (Jürimäe et al., 2008). It is well known that the power of jumping is higher in subjects rich in fast-twitch muscle fibers than in subjects with high percentage of slow-twitch muscle fibers (Bosco et al., 1986). B. Buehring et al. (2010) found that jump power is higher in younger (20-30 years of age) comparing to older $(60+)$ populations. Their study also found that jump height and power were positively correlated with percent lean mass at the hip. Many of these factors were not taken into account in our study. Nevertheless, the present investigation provides some significant insights in the area of bone mineral density relationships with the jumping height in adolescent female athletes with regard to menarche. It is interesting to note, that in the present study CMJ did not correlate with measured BMD variables in the studied girls. Similar trends were revealed in our previous study of pubertal girls with different physical activity patterns (Gruodyte et al., 2009). Another study has also demonstrated that single vertical jumping height was not among the signicant predictors of legs BMD in prepubertal children (Jürimäe et al., 2008). Accordingly, these results suggest that continuous high-impact activities are more important to bone health compared to single jumping activities in physically active premenarcheal girls.

\section{CONCLUSIONS AND PERSPECTIVES}

In conclusion we may suggest that powerful repetitive vertical jumping may be more beneficial to bone health in physically active girls prior to menarche rather than after it. Significant associations after adjusting for age, height, and body mass were found between BMD at femoral neck and rebound jumps for 15 and 30 seconds in pre-menarcheal, but not in post-menarcheal physically active girls. 


\title{
REFERENCES
}

Barkai, H. S., Nichols, J. F., Rauh, M. J. et al. (2007). Influence of sports participation and menarche on bone mineral density of female high school athletes. The Journal of Science and Medicine in Sport, 10, 170-179. Bosco, C., Tihanyi, J., Latteri, F. et al. (1986). The effect of fatigue on store and re-use of elastic energy in slow and fast types of human skeletal muscle. Acta Physiologica Scandinavica, 128 (1), 109-117.

Buehring, B., Krueger, D., Binkley, N. (2010). Jumping mechanography: A potential tool for sarcopenia evaluation in older individuals. Journal of Clinical Densitometry: Assessment of Skeletal Health, 13 (3), 283-291.

Gruodyte, R., Jürimäe, J., Saar, M. et al. (2009). Relationships between areal bone mineral density and jumping height in pubertal girls with different physical activity patterns. The Journal of Sports Medicine and Physical Fitness, 49 (4), 474-479.

Gunter, K., Baxter-Jones, A. D. G., Mirwald, R. L. et al. (2008). Impact exercise increases BMC during growth: An 8-year longitudinal study. Journal of Bone and Mineral Research, 23 (7), 986-993.

Heinonen, A., Sievinen, H., Kannus, P. et al. (2000). High impact exercise and bones of growing girls: A 9-month controlled trial. Osteoporosis International, 11, 1010-1017.

Hind, K., Burrows, M. (2007). Weight-bearing exercise and bone mineral accrual in children and adolescents: $\mathrm{A}$ review of controlled trials. Bone, 40, 14-27.

Jürimäe, T., Hurbo, T., Jürimäe, J. (2008). Relationships between legs bone mineral density, anthropometry and jumping height in prepubertal children. Collegium Antropologicum, 32 (1), 61-66.
Kato, T., Terashima, T., Yamashita, T. et al. (2006). Effect of low-repetition jump training on bone mineral density in young women. Journal of Applied Physiology, 100, 839-843.

Kellis, S. E., Tsitskaris, G. K., Nikopoulou, M. D., Mousikou, K. C. (1999). The evaluation of jumping ability of male and female basketball players according to their chronological age and major leagues. The Journal of Strength and Conditioning Research, 13, 40-46.

MacKelvie, K. J., Khan, K. M., McKay, H. A. (2002). Is there a critical period for bone response to weightbearing exercise in children and adolescents? A systematic review. British Journal of Sports Medicine, 36, 250-257.

MacKelvie, K. J., Khan, K. M., Petit, M. A., Janssen, P. A., MacKay, H. A. (2003). A school-based exercise intervention elicits substantial bone health benefits: A 2-year randomized controlled trial in girls. Pediatrics, 112 (6), e447-452.

Manore, M. M., Kam, L. C., Loucks, A. B. (2007). The female athlete triad: Components, nutrition issues, and health consequences. The Journal of Sports Sciences, 25, S 61-71.

Misra, M. (2008). Bone density in the adolescent athlete. Reviews in Endocrine \& Metabolic Disorders, 9, 139144.

Pepper, M., Saint-Phard, D. (2007). Bone health concerns in active and athletic women and girls. Orthopedics, 30 (4), 281-287.

Rizzoli, R., Bianchi, M. L., Garabedian, M. et al. (2010). Maximizing bone mineral mass gain during growth for the prevention of fractures in the adolescents and the elderly. Bone, 46, 294-305.

\section{SPORTUOJANČIŲ MERGAIČIŲ KAULŲ MINERALINIO TANKIO IR ŠUOLIŲ AUKŠČIO SĄSAJOS MENARCHĖS POŽIŪRIU}

\author{
Rita Gruodyte் ${ }^{1,2}$, Toivo Jürimäe ${ }^{3}$ \\ Lietuvos kūno kultūros akademija ${ }^{1}$, Kaunas, Lietuva \\ Saskačevano universitetas ${ }^{2}$, Saskačevanas, Kanada \\ Tartu universitetas ${ }^{3}$, Tartu, Estija
}

\section{SANTRAUKA}

Tyrimo pagrindimas ir hipotezė. Šoklumo ypatybès ir kaulų sveikatos rodikliai yra tarpusavyje susiję. Teigiamas reguliarios mechaninės griaučių apkrovos poveikis yra didesnis, kai sportuoti pradedama iki prasidedant menarchei. Tyrimu tikrinama hipotezė, kad sąsajos tarp šoklumo ir kaulų sveikatos rodiklių labiau pasireiškia tarp sportuojančiu mergaičiu, dar nepatyrusių menarchès.

Tikslas: nustatyti pubertetinio amžiaus fiziškai aktyvių mergaičiu kaulų mineralinio tankio (KMT) ir šoklumo rodiklių sąsajų priklausomumą nuo menarchès. 
Metodai. Buvo tiriama 113 sveikų 13-15 m. amžiaus mergaičiu, reguliariai lankiusių gimnastikos, badmintono, rankinio, krepšinio, lengvosios atletikos (trumpujų nuotolių bègimo) ir lygumų slidinèjimo pratybas. Atsižvelgiant i tai, ar mergaitès jau buvo patyrusios pirmąsias mėnesines, buvo sudarytos dvi grupès: iki ir po menarchès $(\mathrm{n}=36$ ir 77 atitinkamai). Nustatytas šlaunikaulio kaklelio ir juosmeninès stuburo dalies KMT. Išmatuoti tiriamujų šoklumo (maksimalaus vertikalaus šuolio, 15 ir 30 sekundžių trukmės maksimalių vertikalių šuolių serijos $(\mathrm{cm})$ ) rodikliai.

Rezultatai. Atmetus pagrindinių KMT lemiančių veiksnių (t. y. amžiaus, ūgio ir kūno masès) poveikị, statistiškai reikšmingi koreliaciniai ryšiai nustatyti tik tarp šlaunikaulio kaklelio KMT ir šuolių aukščio 15 bei 30 sekundžių trukmès maksimalių vertikalių šuolių serijų metu tarp fiziškai aktyvių mergaičių, nepatyrusių menarchès $(\mathrm{r}=0,37-$ $0,46 ; \mathrm{p}<0,05)$. Tarp KMT ir šoklumo rodiklių menarchę patyrusiujų grupeje, tarp KMT ir maksimalaus vertikalaus šuolio aukščio abiejose grupèse nustatyti statistiškai nereikšmingi koreliaciniai ryšiai $(p>0,05)$.

Aptarimas ir išvados. Išanalizavus tyrimo rezultatus galima teigti, kad mechaninè griaučių apkrova (pvz., 15 ir 30 sekundžių trukmés maksimalių vertikalių šuolių serijos) gali teigiamiau veikti reguliariai sportuojančiu paaugliu mergaičių kaulų masę iki prasidedant menarchei nei po jos

Raktažodžiai: kaulų sveikata, vertikalūs šuoliai, paauglystè.

Gauta 2010 m. kovo 16 d.

Received on March 16, 2010

Priimta $2011 \mathrm{~m}$. birželio $16 \mathrm{~d}$.

Accepted on June 16, 2011
Corresponding author Rita Gruodytė

Lithuanian Academy of Physical Education

Sporto str. 6, LT-44221 Kaunas

Lithuania

Tel +370 37302669

E-mail r.gruodyte@1kka.1t 